\title{
Pengaruh Fermentasi Kulit Buah Naga Dengan Kapang Neurospora Crassa Terhadap Kandungan Lemak Kasar, Kalsium (Ca) Dan Posfor (P)
}

\section{Effects of Fermentation of Dragon Fruit Skin with Neurospora Crassa Molds on Crude Fat Content, Calcium (Ca) and Posfor (P)}

\author{
Doharni Pane ${ }^{1}$, Rahmaini Pakpahan ${ }^{2}$ \\ 1 dan 2 Program Studi Peternakan, Fakultas Pertanian, Universitas Graha Nusantara \\ Jl. Sutan Soripada Mulia No. 17 Padangsidimpuan 22715 \\ Email :doharnepane1983@gmail.com
}

\begin{abstract}
ABSTRAK
Tujuan penelitian ini untuk mengetahui pengaruh lama fermentasi yang berbeda pada kulit buah naga (KBN) dengan kapang Neurospora crassa (Nc) terhadap perubahan kandungan lemak kasar, Kalsium (Ca) dan Posfor (P). Metode penelitian ini berupa metode eksperimen menggunakan Rancangan Acak Lengkap (RAL) dengan 5 perlakuan dan 4 ulangan. Perlakuannya yaitu $A=$ Fermentasi KBN dengan kapang Nc selama 0 hari, B = Fermentasi KBN dengan kapang Nc selama 4 hari, $\mathrm{C}=$ Fermentasi $\mathrm{KBN}$ dengan kapang Nc selama 6 hari, $\mathrm{D}=$ Fermentasi $\mathrm{KBN}$ dengan kapang Nc selama 8 hari, dan $E=$ Fermentasi KBN dengan kapang Nc selama 10 hari. Hasil penelitian menunjukkan bahwa perbedaan lama fermentasi KBN dengan kapang Nc memberikan pengaruh yang sangat signifikan $(P<0,01)$ terhadap perubahan kandungan lemak kasar, Kalsium $(\mathrm{Ca})$ dan Posfor (P). Berdasarkan hasil penelitian dapat ditarik kesimpulan bahwa fermentasi KBN dengan kapang Nc dapat meningkatkan nilai kandungan lemak kasar, Kalsium (Ca) dan Posfor (P), dalam hal ini terjadi peningkatan kandungan lemak kasar sebesar $0,15 \%$, Kalsium (Ca) meningkat sebesar $0,07 \%$ dan Posfor $(P)$ meningkat sebesar $1,06 \%$.
\end{abstract}

Kata kunci : kbn, neurospora crassa, fermentasi

The purpose of this study was to determine the effect of different fermentation times on the skin of dragon fruit (KBN) with fungi Neurospora crassa (Nc) on changes in crude fat content, Calcium (Ca) and Posfor $(\mathrm{P})$. This research method is an experiment using a completely randomized design (CRD) with 5 treatments and 4 replications. The treatments are $A=$ Fermentation of KBN with Nc fungi for 0 days, $B=$ Fermentation of $K B N$ with $N c$ fungi for 4 days, $C=$ Fermentation of $K B N$ with Nc fungi for 6 days, $D=$ Fermentation of $K B N$ with Nc fungi for 8 days, and $E=$ Fermentation KBN with kapok Nc for 10 days. The results showed that the difference in KBN fermentation time with Nc mold gave a very significant effect $(P<0.01)$ on changes in crude fat content, Calcium $(\mathrm{Ca})$ and Posfor $(P)$. Based on the results of the study it can be concluded that KBN fermentation with Nc mold can increase the value of crude fat content, Calcium ( $\mathrm{Ca}$ ) and Posfor $(\mathrm{P})$, in this case an increase in crude fat content of $0.15 \%$, Calcium $(\mathrm{Ca})$ increases by $0,07 \%$ and Posfor $(P)$ increased by $1.06 \%$.

Keywords : kbn, neurospora crassa, fermentation

\section{PENDAHULUAN}

Penyediaan pakan ternak di Indonesia saat ini masih mengalami kendala, diantaranya adalah masih tingginya komponen penyusun pakan berupa pakan import dan ketersediaannya pakan yang tidak kontinyu sepanjang tahun. Sekitar $60-70 \%$ dari seluruh biaya produksi digunakan untuk penyediaan pakan (Siregar dkk, 1980). Berbagai penelitian telah banyak dilakukan untuk memanfaatkan limbah yang tidak berharga menjadi bahan pakan yang nilai biologisnya tinggi dan memberikan nilai tambah. Kulit buah naga (dragon fruit) merupakan salah satu contoh limbah pertanian yang layak dicoba sebagai campuran ransum karena berbagai potensi dan kelebihannya. Persentase berat kulit buah naga 
mencapai $30-35 \%$ dari keseluruhan buah naga (Nurliyana et al., 2010).

Kulit buah naga merah memiliki kandungan antioksidan yang lebih tinggi dibandingkan daging buahnya (Daniel, 2014). Kulit buah naga memiliki zat warna alami antosianin cukup tinggi. Antosianin adalah zat warna yang berperan dalam memberikan warna merah berpotensi menjadi pewarna alami yang lebih aman bagi kesehatan. Kulit buah naga masih jarang atau bahkan belum dimanfaatkan sepenuhnya karena masih belum diketahui kandungan zat makanan dan mineralnya meskipun pada beberapa penelitian terdahulu telah dilaporkan bahwa kulit buah naga merah memiliki kandungan pigmen merah antosianin yang cukup tinggi.

Kulit buah naga merah mengandung nutrien yang cukup baik yaitu protein 8,98\%, serat kasar $25,56 \%$, lemak $2,60 \%$, energi $3.195,9 \mathrm{Kkal} / \mathrm{kg}$, kalsium $1,82 \%$ dan posfor 0,002\% (Fardiaz, 1998). Dilihat dari segi potensi dan gizi yang terkandung didalamnya maka kulit buah naga merupakan bahan yang cukup potensinya untuk digunakan sebagai pakan. Untuk meningkatkan kualitas kulit buah naga sehingga pemanfaatannya dalam ransum ternak dapat maksimal, maka dapat dilakukan upaya biologis melalui fermentasi dengan kapang. Pengolahan makanan dengan metode biologis dengan fermentasi prinsipnya adalah sebagai pengaktif pertumbuhan dan metabolisme dari mikroorganisme yang dibutuhkan sehingga membentuk produk yang berbeda dengan bahan asalnya (Fardiaz dan Winarno, 1980). Proses fermentasi diartikan sebagai proses pemecahan karbohidrat dan asam amino anaerobik, yaitu tanpa memerlukan oksigen (Nuraini dan Marlida, 2005). Salah satu mikroba yang digunakan dalam fermentasi adalah Neurospora crassa. Kapang Neurospora crassa merupakan kapang yang dapat melakukan hidrolisis protein komplek menjadi peptida-peptida dan asamasam amino bebas, mampu menghasilkan enzim amilase dan hemiselulase, serta merupakan kapang penghasil $\beta$-karoten tertinggi yang telah diisolasi dari tongkol jagung (Nuraini, 2006).

Kapang Neurospora crassa adalah kapang yang dapat menghidrolisis protein komplek menjadi peptide-peptida dan asam-asam amino bebas, mampu menghasilkan enzim amilase dan hemiselulase. Hasil penelitian Nuraini dan Marlida (2005) menyatakan kapang Neurospora crassa merupakan kapang penghasil $\beta$-karoten tertinggi yang telah diisolasi dari tongkol jagung.Senyawa $\beta$-karoten adalah senyawa karotenoid yang berfungsi sebagai provitamin $A$, sebagai pemberi warna kuning pada kuning telur dan dapat menurunkan kolesterol kuning telur (Nuraini, 2006). Kapang Neurospora crassa dapat menghasilkan enzim amilase, enzim selulase dan enzim protease (Nuraini, 2006). Hasil penelitian Nuraini et al. (2009) menunjukkan onggok setelah difermentasi dengan kapang Neurospora crassa dengan dosis inokulum $9 \%$, lama fermentasi 7 hari dan ketebalan substrat $2 \mathrm{~cm}$ diperoleh kandungan protein kasar meningkat dari 3,06\% sebelum fermentasi menjadi $18,94 \%$ sesudah fermentasi, kandungan serat kasar turun dari $19,45 \%$ sebelum fermentasi menjadi 16,75\% sesudah fermentasi dan kandungan zat- zat makanan lainnya adalah lemak 2,25\%, kalsium $0,22 \%$, phosfor $0,02 \%$, BETN $52,25 \%$ dan $\beta-$ karoten 270,60 mg/kg.

Nuraini dkk. (2007) menyatakan fermentasi kulit ubi kayu dengan kapang Neurospora crasa hanya dapat menurunkan serat kasar sekitar 50 persen dari serat kasar kulit ubi kayu, karena kapang Neurospora crasa tersebut sedikit menghasilkan enzim selulase. Ditambahkan bahwa keberhasilan fermentasi media padat sangat tergantung pada kondisi optimum yang diberikan. $\quad$ Faktor-faktor yang mempengaruhinya adalah komposisi dan ketebalan subtrat, dosis inokulum, lama fermentasi serta suhu dan $\mathrm{pH}$. Semakin tinggi dosis maka semakin cepat pertumbuhan mikroba dan semakin lama fermentasi dilakukan maka semakin banyak pula zat makanan dirombak (Winarno, 1980). Berdasarkan latar belakang di atas, maka penelitian ini berfokus untuk mengetahui lama fermentasi yang berbeda antara kulit buah naga dengan kapang Neurospora crassa terhadap perubahan kandungan lemak kasar, kalsium (Ca) dan posfor (P), sehingga dapat dimanfaatkan sebagai bahan baku pakan yang berkualitas. Hasil penelitian ini secara umum diharapkan dapat memberikan informasi serta wawasan dalam rangka mencari pakan alternatif yang berkualitas.

\section{METODOLOGI PENELITIAN Materi Penelitian}

Bahan-bahan yang digunakan pada penelitian ini adalah kulit buah naga, kapang Neurospora crassa. Bahan kimia untuk analisa lemak kasar, Kalsium (Ca) dan Posfor (P).

Peralatan yang digunakan adalah kantong plastik, timbangan analitik, pisau, baskom, kukusan, talenan, sendok pengaduk serta peralatan untuk analisis lemak kasar, Kalsium (Ca) dan Posfor(P).

\section{Rancangan Percobaan}

Metode yang digunakan pada penelitian ini adalah eksperimen dengan Rancangan Acak 
Lengkap (RAL) 5 (lima) perlakuan dengan 4 (empat) kali ulangan. Perlakuannya adalah fermentasi kulit buah naga dengan kapang Neurospora crassa dengan lama fermentasi yang terdiri atas 5 (lima) level yaitu :

$\mathrm{A}=$ fermentasi kulit buah naga dengan kapang Neurospora crassa 0 hari

$B=$ fermentasi kulit buah naga dengan kapang Neurospora crassa 4 hari

$\mathrm{C}=$ fermentasi kulit buah naga dengan kapang Neurospora crassa 6 hari

$D=$ fermentasi kulit buah naga dengan kapang Neurospora crassa 8 hari

$E=$ fermentasi kulit buah naga dengan kapang Neurospora crassa 10 hari

Peubah yang diamati adalah lemak kasar, Kalsium (Ca) dan Posfor (P). Data yang diperoleh dianalisis dengan sidik ragam. Jika terdapat perbedaan perlakuan, maka perbedaan antar perlakuan diuji dengan Duncan's Multiple Range Test/DMRT (Steel and Torrie, 1995). Model matematis dari rancangan yang digunakan menurut Steel and Torie (1995) adalah :

$$
Y_{i j}=\mu+T_{i}+\varepsilon_{i j}
$$

Keterangan :

$$
\begin{aligned}
Y_{i j} & =\text { nilai pengamatan } \\
\mu & =\text { nilai tengah umum } \\
\mathrm{T}_{\mathrm{i}} & =\text { pengaruh perlakuan ke-i } \\
\varepsilon_{\mathrm{ij}} & =\text { pengaruh unit perlakuan ke-i dan } \\
& \text { ulangan ke-j }
\end{aligned}
$$

Pelaksanaan Penelitian Proses Pembuatan Tepung Kulit Buah Naga (KBN)

Kotoran yang melekat pada kulit buah naga dibersihkan, kemudian dicincang dan dikeringkan. KBN yang telah kering, lalu digiling sehingga menjadi tepung KBN.

\section{Fermentasi Kulit Buah Naga (KBN) dengan Kapang Neurospora crassa}

Kantong plastik kaca berukuran $500 \mathrm{gr}$ disiapkan sebanyak 20 buah, lalu masingmasing diberi label dan lilin. Larutan urea $2 \%$ dibuat dengan melarutkan 2 gr urea dalam 100 $\mathrm{ml}$ akuades. Substrat KBN ditimbang sebanyak $100 \mathrm{gr}$, lalu dimasukkan ke dalam kantong plastik. Kemudian substrat dalam kantong plastik ditambahkan dengan 2,5 ml larutan urea dan $30 \mathrm{ml}$ aquades, kemudian diaduk dalam kantong plastik sampai homogen. Kemudian substrat dalam plastik disterilisasi menggunakan pengukus (suhu $100^{\circ} \mathrm{C}$ selama 30 menit), biarkan hingga suhu turun mencapai suhu kamar, kemudian diangkat dan didinginkan di dalam ruangan steril. Setelah itu substrat steril dalam kantong plastik diinokulasikan dengan $9 \%$ inokulum
Neurospora crassa (Nuraini et al., 2009) di dalam ruangan steril dengan cara substrat dan inokulum diaduk/dicampur sampai homogen, selanjutnya ditutup dengan membakar ujung plastik dengan lilin, kemudian diinkubasi/diperam pada suhu kamar selama 0 hari (perlakuan $\mathrm{A} /$ kontrol), 4 hari (perlakuan B), 6 hari (perlakuan C) dan 8 hari (perlakuan D) dan 10 hari (Perlakuan E) dengan menatanya di atas nampan keranjang persegi empat. Setelah proses inkubasi/pemeraman berakhir maka produk fermentasi kemudian ditimbang berat segarnya, kemudian dikeringkan di bawah sinar matahari selama \pm 10 jam untuk mematikan kapang. Setelah itu diaduk merata, digiling, dan diambil sampelnya untuk analisa lemak kasar, Kalsium (K) dan Posfor (P).

\section{PEMBAHASAN}

1. Perubahan Kandungan Lemak Kasar Kulit Buah Naga Fermentasi (KBNF)

Rataan kandungan lemak kasar kulit buah naga yang difermentasi dengan kapang Neurospora crassa untuk masing-masing perlakuan dapat dilihat pada Tabel 1.

Tabel 1. Kandungan lemak kasar kulit buah naga fermentasi (KBNF)

\begin{tabular}{cc}
\hline Perlakuan & Lemak Kasar (\%) \\
\hline A & $1,46 \pm 0,07^{\mathrm{b}}$ \\
B & $1,54 \pm 0,06^{\mathrm{a}}$ \\
C & $1,60 \pm 0,02^{\mathrm{a}}$ \\
D & $1,59 \pm 0,05^{\mathrm{a}}$ \\
E & $1,61 \pm 0,01^{\mathrm{a}}$ \\
\hline Keterangan: Superskrip yang berbeda pada kolom yang \\
sama menunjukkan pengaruh yang berbeda \\
sangat nyata $(\mathrm{P}<0,01)$ \\
$\mathrm{A}=$ lama fermentasi 0 hari \\
$\mathrm{B}=$ lama fermentasi 4 hari \\
$\mathrm{C}=$ lama fermentasi 6 hari \\
$\mathrm{D}=$ lama fermentasi 8 hari \\
$\mathrm{E}=$ lama fermentasi 10 hari
\end{tabular}

Kandungan lemak kasar kulit buah naga hasil fermentasi dengan Neurospora crassa berkisar antara 1,46\% sampai 1,61\% (Tabel 1). Kandungan lemak kasar perlakuan B, C, D dan $E$ berbeda nyata dibandingkan dengan kandungan lemak kasar pada perlakuan A (lama fermentasi 0 hari). Peningkatan lemak kasar paling tinggi diperoleh pada perlakuan $\mathrm{E}$ (lama fermentasi 10 hari) yaitu sebesar 0,15\% (dari 1,46 menjadi 1,61\%). Hasil penelitian ini sedikit berbeda dengan hasil penelitian lain tentang fermentasi yang umumnya menurunkan kadar lemak pada produk fermentasi. Hal tersebut berarti selama proses fermentasi terjadi peningkatan kadar lemak. Meningkatnya kadar lemak hasil fermentasi disebabkan 
karena proses fermentasi berlangsung dengan baik.

Penelitian Azwar dan Melati (2010) memperlihatkan adanya penurunan lemak yang cukup tinggi pada tepung kulit ubi kayu yang difermentasi menggunakan $T$. viride dengan dosis $9 \%$ dengan waktu fermentasi 7 hari yaitu sebesar $89,43 \%$ (dari 3,5\% menjadi 0,37\%). Hasil penelitian Melati et al. (2009) juga menunjukkan hal yang sama, dimana terjadi penurunan lemak pada ampas tahu yang difermentasi menggunakan $A$. niger dengan dosis $9 \%(\mathrm{v} / \mathrm{b})$ dan waktu fermentasi 7 hari yaitu sebesar $77,54 \%$ (dari $3,5 \%$ menjadi $0,37 \%$ ). Peningkatan kandungan lemak kasar pada kulit buah naga hasil fermentasi diduga terjadi karena kapang dapat mengubah karbohidrat pada media/subtrat menjadi lemak yang selanjutnya diakumulasikan sebagai lemak sel. Nuraida et al. (1996) menyatakan bahwa karbohidrat merupakan sumber $\mathrm{C}$ terbaik untuk pertumbuhan kapang dan sekitar $15 \%-18 \%$ gula yang tersedia dalam media akan diubah menjadi lemak. Kapang merupakan mikroorganisme yang secara efisien dapat mengubah glukosa menjadi lemak (Wassef, 1977).

2. Perubahan Kandungan Kalsium (Ca) Kulit Buah naga Fermentasi (KBNF)

Rataan kandungan Kalsium (Ca) kulit buah naga yang difermentasi dengan kapang neurospora crassa untuk masing-masing perlakuan dapat dilihat pada Tabel 2.

Tabel 2. Kandungan Kalsium (Ca) kulit buah naga fermentasi (KBNF)

\begin{tabular}{cc}
\hline Perlakuan & Kalsium (Ca) (\%) \\
\hline A & $0,27 \pm 0,02^{\mathrm{b}}$ \\
B & $0,29 \pm 0,01^{\mathrm{ab}}$ \\
C & $0,34 \pm 0,04^{\mathrm{a}}$ \\
D & $0,33 \pm 0,03^{\mathrm{a}}$ \\
E & $0,33 \pm 0,05^{\mathrm{a}}$
\end{tabular}

Keterangan: Superskrip yang berbeda pada kolom yang sama menunjukkan pengaruh yang berbeda sangat nyata $(P<0,01)$

$\mathrm{A}=$ lama fermentasi 0 hari

$\mathrm{B}=$ lama fermentasi 4 hari

$\mathrm{C}=$ lama fermentasi 6 hari

$\mathrm{D}=$ lama fermentasi 8 hari

$\mathrm{E}=$ lama fermentasi 10 hari

Berdasarkan Tabel 2 ternyata pada kulit buah naga hasil fermentasi terjadi peningkatan kandungan kalsium bila dibandingkan dengan kontrol (perlakuan A) yang kandungan kalsiumnya $0,27 \%$. Hal ini sesuai dengan pendapat Sternberg (1976) bahwa dengan melakukan fermentasi suatu bahan dapat terjadi perubahan $\mathrm{pH}$, kelembaban, suhu, aroma serta penambahan nilai gizi yang mencakup peningkatan nilai gizi, vitamin dan mineral, dimana kalsium merupakan salah satu nutrisi sumber mineral.

Selanjutnya Penderson

menyatakan bahwa selama fermentasi berlangsung akan terjadi perubahan kandungan asam amino, lemak, karbohidrat, vitamin dan mineral yang diakibatkan oleh aktivitas dan perkembangbiakan dari mikroorganisme di dalam sel media selama proses fermentasi berlangsung.

\section{Perubahan Kandungan Posfor (P) Kulit} Buah naga Fermentasi (KBNF)

Rataan kandungan Posfor (P) kulit buah naga yang difermentasi dengan kapang neurospora crassa untuk masing-masing perlakuan dapat dilihat pada Tabel 3.

Tabel 3. Kandungan Posfor (P) kulit buah naga fermentasi (KBNF)

\begin{tabular}{cc}
\hline Perlakuan & Posfor $(P)(\%)$ \\
\hline A & $0,25 \pm 0,01^{\mathrm{b}}$ \\
B & $0,23 \pm 0,04^{\mathrm{b}}$ \\
C & $1,31 \pm 0,04^{\mathrm{a}}$ \\
D & $1,31 \pm 0,03^{\mathrm{a}}$ \\
E & $1,27 \pm 0,05^{\mathrm{a}}$ \\
\hline
\end{tabular}

Keterangan: Superskrip yang berbeda pada kolom yang sama menunjukkan pengaruh yang berbeda sangat nyata $(P<0,01)$

$A=$ lama fermentasi 0 hari

$\mathrm{B}=$ lama fermentasi 4 hari

$\mathrm{C}=$ lama fermentasi 6 hari

$\mathrm{D}=$ lama fermentasi 8 hari

$\mathrm{E}=$ lama fermentasi 10 hari

Tabel 3 menunjukkan bahwa rataan kandungan posfor tertinggi terdapat pada perlakuan C (lama fermentasi 6 hari) dan D (lama fermentasi 8 ) yaitu $1,31 \%$ dan yang terendah pada perlakuan B (lama fermentasi 4 hari) yaitu $0,23 \%$. Hasil analisis keragaman menunjukkan bahwa perbedaan lama fermentasi dengan kapang Neurospora crassa memberikan pengaruh yang berbeda sangat nyata $\quad(P<0,01) \quad$ terhadap peningkatan kandungan posfor KBNF. Perlakuan $C$ dan $D$ merupakan perlakuan yang optimum dalam menghasilkan kandungan posfor tertinggi.

Uji lanjut Duncan's Multiple Range Test/DMRT menunjukkan kadar fosfor dengan lama fermentasi 8 hari (perlakuan D) mempunyai kandungan fosfor tertinggi, akan tetapi tidak berbeda nyata dengan lama fermentasi 6 hari (perlakuan C). Hal ini diduga semakin tinggi waktu fermentasi akan mengakibatkan pertumbuhan kapang lebih sedikit menggunakan fosfor. Hal ini sesuai dengan pendapat Sukara dan Atmowidjojo 
(1970), bahwa kapang yang mempunyai perkembangbiakan yang lebih baik akan memecah komponen menjadi massa sel penyusun media.

\section{KESIMPULAN}

Berdasarkan hasil penelitian yang telah dilakukan, dapat disimpulkan bahwa lama fermentasi kulit buah naga dengan kapang Neurospora crassa berpengaruh terhadap peningkatan nilai kandungan lemak kasar, kalsium $(\mathrm{Ca})$ dan posfor $(\mathrm{P})$, dalam hal ini lama fermentasi 10 hari (perlakuan E) merupakan perlakuan terbaik. Pada perlakuan E diperoleh hasil peningkatan kandungan lemak kasar sebesar 0,15\%, peningkatan kandungan kalsium (Ca) sebesar 0,07\%, dan posfor (P) meningkat sebesar $1,06 \%$.

\section{DAFTAR PUSTAKA}

Azwar, Z.I. \& Melati, I. 2010. Perbaikan kualitas tepung kulit ubi kayu melalui fermentasi menggunakan Trichoderma viride. Prosiding Simposium Nasional Bioteknologi Akuakultur III. Fakultas Perikanan dan IImu Kelautan, Institut Pertanian Bogor, hlm. 64-72.

Daniel, R. 2014. Kajian kandungan zat makanan dan pigmen antosianin tiga jenis kulit buah naga (Hylocereus sp.) sebagai bahan pakan ternak. Universitas Brawijaya: Fakultas Peternakan.

Fardiaz, S., F.G. Winarno. 1980. Pengantar Teknologi Pangan. Gramedia Jakarta.

Fardiaz, S. 1998. Fisiologi Fermentasi, PAU Pangan dan Gizi, IPB. Bogor.

Melati, I., Azwar, Z.I., \& Kurniasih, T. 2009. Pemanfaatan ampas tahu terfermentasi sebagai susbtitusi tepung kedelai dalam formulasi ikan patin. Prosiding Forum Inovasi Teknologi Akuakultur. Pusat Riset Perikanan Budidaya, hlm. 713-719.

Nuraida, L., Niehaber, N.L.P., Winarno, Swandoko, G.A., \& Rahman, A. 1996. Pengaruh kondisi fermentasi terhadap produksi minyak kapang Mucoinaequisporus M 05II/4. Bul. Tek. dan Industri Pangan, VII(I): 79-86.

Nuraini. 2006. Potensi kapang karotenogenik untuk memproduksi pakan sumber $\beta$-karoten dan pengaruhnya terhadap ransum ayam pedaging dan petelur. Disertasi. Program Pasca Sarjana Universitas Andalas, Padang.

Nuraini, S. A. Latif dan Sabrina. 2007. Peningkatan kualitas limbah aroindustri dengan kapang Neurospora crasa sebagai pakan ternak unggas. Laporan penelitian hibah bersaing, DIKTI.
Lembaga Penelitian Universitas Andalas, Padang.

Nuraini, Sabrina and Suslina A. Latif. 2009. Improving the quality of tapioca by product through fermentation by Neurospora crassa to produce $\beta$ carotene rich feed. Pakistan Jurnal of Nutrition. 8(4):487-490.

Nurliyana, R., I. Syed Zahir., K.M. Suleiman., M.R Aisyah and K. Kamarul Rahim. 2010. Antioxidant study of pulps and peels of dragon fruit: A Comparative Study. International Food Research Journal. 17: 367- 375.

Pederson, C. 1971. Microbiology of Food Fondation. The AVI Publ-Co. Inc, Westport, Cannedicut.

Siregar, A.P., M. Sabrani dan S. Pramu. 1980. Teknik Modern Beternak Ayam. CV. Yasaguna, Jakarta.

Steel. R.G.D, dan Torrie, J.H. 1995. Prinsip dan Prosedur Statistik. Suatu Pendekatan Biometric P.T Gramedia Pustaka Utama Jakarta.

Sternberg, D. 1976. Production of cellulase by Trichoderma. Di dalam E.L. Gaden Jr (ed) 1976. Enzymatic conversion of cellulotic material; Tecnology and Application.

Sukara, E. Dan A.H. Atmowidjojo. 1970. Pemanfaatan ubi kayu untuk produksi enzim amilasi dan protein sel tunggal:optimasi nutrisi untuk proses fermentasi substrat cair dengan menggunakan kapang Rhizopus Proc. Seminar Nasional. UPT-EPG, Lampung. P. 506- 517

Wassef, M.K. 1977. Fungal Lipids. In. Paoletti, A. \& Kritchersky, D. (Eds.). Advanced in Lipid Research. Academic Press. New York, p.159-230.

Winarno, F. G. S. Fardiaz dan D. Fardiaz. 1980. Pengantar Teknologi Pangan. PT. Gramedia. Jakarta. 